\title{
Relationships of maternal zinc intake from animal foods with fetal growth
}

Yo A. Lee ${ }^{1}$, Ji-Yun Hwang ${ }^{6}$, Hyesook Kim ${ }^{1}$, Eun-Hee $\mathrm{Ha}^{2}$, Hyesook Park ${ }^{2}$, Mina Ha ${ }^{3}$, Yangho Kim ${ }^{4}$, Yun-Chul Hong ${ }^{5}$ and Namsoo Chang ${ }^{1 *}$

${ }^{1}$ Department of Nutritional Science and Food Management, Ewha Womans University, 11-1 Daebyun-dong, Seodaemun-gu, Seoul 120-750, Republic of Korea

${ }^{2}$ Department of Preventive Medicine, College of Medicine, Ewha Womans University, Seoul, Republic of Korea

${ }^{3}$ Department of Preventive Medicine, Dankook University College of Medicine, Cheonan, Republic of Korea

${ }^{4}$ Department of Occupational and Environmental Medicine, Ulsan University Hospital, University of Ulsan College of

Medicine, Ulsan, Republic of Korea

${ }^{5}$ Department of Preventive Medicine, Seoul National University College of Medicine, Seoul, Republic of Korea

${ }^{6}$ Graduate School of Education, Sangmyung University, 7 Hongi-dong Jongno-gu, Seoul 110-743, Republic of Korea

(Received 5 July 2010 - Revised 9 December 2010 - Accepted 13 December 2010 - First published online 22 February 2011)

\section{Abstract}

$\mathrm{Zn}$ is an essential element for human growth. The nutritional adequacy of dietary Zn depends not only on the total $\mathrm{Zn}$ intake, but also on the type of food source (i.e. of plant or animal origin). We investigated the association between maternal dietary $\mathrm{Zn}$ intake from animal and plant food sources and fetal growth. A total of 918 pregnant women at 12-28 weeks of gestation were selected from the Mothers and Children's Environmental Health study in Korea. Dietary intakes in mid-pregnancy were estimated by a $24 \mathrm{~h}$ recall method, and subsequent birth weight and height were obtained from medical records. Multiple regression analysis showed that maternal $\mathrm{Zn}$ intake from animal food sources and their proportions relative to total $\mathrm{Zn}$ intake were positively associated with birth weight $(P=0.034$ and 0.045 , respectively) and height ( $P=0.020$ and 0.032 , respectively). Conversely, the percentage of $\mathrm{Zn}$ intake from plant food sources relative to total $\mathrm{Zn}$ intake was negatively associated with birth height $(P=0.026)$ after adjustment for covariates that may affect fetal growth. The molar ratio of phytate:Zn was negatively associated with birth weight $(P=0.037)$. In conclusion, we found that the absolute amounts of $\mathrm{Zn}$ from different food sources (e.g. animal or plant) and their proportions relative to total $\mathrm{Zn}$ intake were significantly associated with birth weight and height. A sufficient amount of $\mathrm{Zn}$ intake from animal food sources of a relatively higher $\mathrm{Zn}$ bioavailability is thus encouraged for women during pregnancy.

Key words: Zinc: Birth weight: Birth height: Pregnant women

$\mathrm{Zn}$ is an essential mineral for normal growth and development, by participating in many enzyme reactions and biological functions including the synthesis of proteins and nucleic $\operatorname{acids}^{(1)}$, bone growth $^{(2)}$, and the initiation of transcription processes, gene expression and cell division ${ }^{(3)}$. The requirement for $\mathrm{Zn}$ is increased during periods of rapid growth, such as pregnancy ${ }^{(4)}$. Earlier studies have reported that $\mathrm{Zn}$ is one of the most important nutrients for pregnancy ${ }^{(4-8)}$; maternal Zn deficiency during pregnancy causes fetal growth retardation, pre-term delivery, low birth weight and effects on postnatal growth and development ${ }^{(4-11)}$.

It is well established that both the total intake of $\mathrm{Zn}$ and its bioavailability, usually measured by the molar ratio of phytate: $\mathrm{Zn}^{(12)}$, are important contributing factors to $\mathrm{Zn}$ nutrition ${ }^{(13)}$. Zn present in animal foods is known to exhibit a greater degree of bioavailability than that in plants because of the possible presence of phytate, which inhibits Zn absorption in the intestine ${ }^{(12,14)}$. However, a high amount of phytate is present in cereals, legumes and nuts, which are often staple foods in Asian countries ${ }^{(15,16)}$, including Korea; approximately $80 \%$ of the total food consumed is of plant origin, the majority being from foods with a relatively low bioavailability, such as white rice, grain products, legumes and vegetables ${ }^{(17)}$. Although processing, such as milling and/or cooking methods that remove both phytate and $\mathrm{Zn}$ from grain products, can improve $\mathrm{Zn}$ bioavailability, the total amount of $\mathrm{Zn}$ in the foods may be very low ${ }^{(15,18)}$.

Despite the well-known variability in the bioavailability of dietary $\mathrm{Zn}$ and the importance of maternal $\mathrm{Zn}$ nutrition for fetal growth, there have been very limited studies. Velie et $a l .{ }^{(19)}$ have reported the positive relationship between maternal $\mathrm{Zn}$ intake from animal sources and the risk of 
neural tube defects; however, they did not include anthropometric measurements, which is a major indicator of fetal growth. Yokoi et al. ${ }^{(20)}$ have reported that consumption of beef and other red meats measured by qualitative food frequency was positively associated with $\mathrm{Zn}$ pool size in premenopausal women.

We hypothesised that the food source of maternal $\mathrm{Zn}$ intake and the molar ratio of phytate:Zn during pregnancy are associated with fetal growth, and the positive association may exist in animal sources only. Moreover, to test this hypothesis, we evaluated the relationship between maternal dietary $\mathrm{Zn}$ intake from different food sources (namely plant and animal) and fetal growth using a large sample from the Mothers and Children's Environmental Health study ${ }^{(21)}$.

\section{Subjects and methods}

\section{Subjects}

The Mothers and Children's Environmental Health study is a prospective cohort study designed to investigate the effect of pre- and postnatal environmental exposures on growth, development and health from early fetal life to young adulthood. The present study was conducted according to the guidelines laid down in the Declaration of Helsinki, and all subjects provided a written informed consent. The study was reviewed and approved by three institutional review boards at Ewha Womans University School of Medicine, Dankook University Hospital and Ulsan University Hospital, and informed consent for participation was obtained from all subjects. The present investigation formed part of a multicentre prospective cohort study of women in mid-pregnancy (12-28 weeks of gestation) conducted in Seoul (a metropolitan area), Ulsan (an industrial area) and Cheonan (a medium-sized urban area), Republic of Korea, as described previously ${ }^{(21,22)}$. Of the 1610 women who participated in the Mothers and Children's Environmental Health study between August 2006 and October 2009, we excluded twenty-five women who were pregnant with twins, twenty-two with spontaneous abortion, twenty-six with pregnancy complications (hypertension and/or diabetes), sixty-six whose pregnancy lasted less than 37 or greater than 42 weeks, 106 without dietary intake data and 447 who had not delivered babies at the time of this analysis. Among the remaining 918 subjects, fifty-six were excluded because they had insufficient data for the covariates that may affect fetal growth. Thus, 862 and 784 subjects were eligible for inclusion in birth-weight and -height analyses, respectively (since birthheight data were missing from seventy-eight subjects).

Using a structured questionnaire, trained personnel interviewed the participants to obtain demographic and socio-economic data, including local centres (Seoul, Ulsan or Cheonan), age (years), weight $(\mathrm{kg})$, height $(\mathrm{cm})$, education (less than high school, less than university or university or higher), family income (<US\$2000, US\$2000-4000 or $>$ US\$4000; median monthly household income per two or more persons in Korea is approximately 3400000 Korean won $=$ approximately US $\$ 2900$ in 2009), exercise (yes or no), ever smoked (yes or no), current smoking (yes or no), alcohol consumption (current or none) and parity ( $n$ ). Pre-pregnancy BMI was calculated using self-reported height and weight. Gestational age at delivery (weeks) was estimated on the basis of the self-reported date of the last menstrual period. Birth weight $(\mathrm{g})$ and height $(\mathrm{cm})$ at delivery were measured by trained nurses, and neonatal sex (girl or boy) was obtained from medical records.

\section{Dietary assessment}

Dietary intake data were obtained from participants by a well-trained dietary interviewer using the $24 \mathrm{~h}$ recall method. Dietary intakes of food groups and nutrients were analysed using a computerised nutrient-intake assessment software program (CAN-Pro 3.0; Korean Nutrition Society, Seoul, Korea). Zn intakes from animal (meat, fish, eggs and dairy products), plant (grains, potatoes, legumes, mushrooms, fruit and vegetables, seaweeds, and nuts) and other (sweets, carbonated beverages, fats and oils, and condiments) food sources were calculated. Percentages of $\mathrm{Zn}$ intake from animal or plant foods were defined as ( $\mathrm{Zn}$ intake from animal or plant foods/total dietary $\mathrm{Zn}$ intake) $\times 100$. To estimate $\mathrm{Zn}$ intake from supplements, information on self-reported supplement use was collected by asking the type (vitamins, minerals and others) and brand name of the supplements, and the amount and frequency of their use.

Phytate intakes were calculated using the phytate content of each food component from the literature ${ }^{(14,15,23)}$. Adjustments were made, when necessary, to take into account any known changes in phytate content arising from food processing and preparation methods. The molar ratio of phytate: $\mathrm{Zn}$ was calculated as the mole of phytate intake (molecular weight, 660.1) divided by the mole of $\mathrm{Zn}$ intake (molecular weight, 65.4). We covered $80.5 \%$ (range $42.9-100 \%$ ) of phytate intake of the subjects.

\section{Statistical analysis}

Statistical analyses were performed using the SAS statistical package (SAS 9.1; SAS Institute, Cary, NC, USA). Nutrient intake data were logarithmically transformed in order to normalise their distributions. Sociodemographic and behavioural characteristics are expressed as means and standard deviations (continuous variables) or as numbers and percentages (categorical variables). Total $\mathrm{Zn}$ intake from food and supplements, total dietary $\mathrm{Zn}$ intake and $\mathrm{Zn}$ intake from animal and plant food sources, individually, were divided into quartiles. For the trend test, the categorical variables (i.e. quartiles of $\mathrm{Zn}$ and phytate intakes, and phytate:Zn ratio) were treated as continuous variables assigned with the median value within each category, after adjustment for covariates, such as maternal age, pre-pregnancy BMI, neonatal sex, gestational age at delivery, parity, level of education, local centres and interaction between level of education and local centres, that may affect fetal growth ${ }^{(22)}$. Multiple regression analysis was used to examine the relationship between maternal $\mathrm{Zn}$ intakes from animal and plant sources and fetal growth. Differences were considered significant at the $5 \%$ level. 


\section{Results}

Our subjects were 30.1 (SD 3.7) years old and had a prepregnancy BMI of 21.7 (SD 3.3$) \mathrm{kg} / \mathrm{m}^{2}$ (Table 1). Approximately, $70 \%$ of the subjects had a university or higher education, and about $56 \%$ were primiparous. Gestational age at delivery was 39.3 (SD 1.1) weeks, and birth weight and height were 3297 (SD 385) g and $50 \cdot 7(\mathrm{SD} 2 \cdot 3) \mathrm{cm}$, respectively.

Energy intake during pregnancy was 1775 (sD 482) kcal/d (7421 (sD 2016) kJ/d; Table 2). Total Zn intake was 9.9 (SD $5.6) \mathrm{mg} / \mathrm{d}(8.4(\mathrm{SD} 3.5) \mathrm{mg} / \mathrm{d}$ from foods and 1.5 (SD 4.4$) \mathrm{mg} / \mathrm{d}$ from supplements). Zn intakes from animal and plant food sources (\% total $\mathrm{Zn}$ intake) were $3.4(\mathrm{sD} 3.0) \mathrm{mg} / \mathrm{d}(37 \cdot 1 \%)$ and $4.8(\mathrm{SD} 1.8) \mathrm{mg} / \mathrm{d}(60.2 \%)$, respectively. Average phytate intake was 626.0 (SD 331.8$) \mathrm{mg} / \mathrm{d}$, and the molar ratio of phytate:Zn was $7 \cdot 7$ (SD 3.8).

As shown in Table 3, multiple regression analysis indicated that maternal $\mathrm{Zn}$ intake from animal food sources and their proportions relative to total $\mathrm{Zn}$ intake were positively associated with birth weight $(P=0.034$ and 0.045 , respectively) and height ( $P=0.020$ and 0.032 , respectively), whereas the percentage of $\mathrm{Zn}$ intake from plant food sources was negatively associated with birth height $(P=0 \cdot 026)$. Phytate intake was not associated with birth weight and height, but the molar ratio of phytate: $\mathrm{Zn}$ was negatively associated with birth weight $(P=0 \cdot 037)$.

A general linear model adjusted for covariates revealed that birth weight increased from the lowest to the highest quartiles of total $\mathrm{Zn}$ intake from foods ( $P$ for trend $=0.039$ ), as did that from animal sources $(P$ for trend $=0.002)$ and their proportion (\%) to total $\mathrm{Zn}$ intake ( $P$ for trend $=0.026$; Table 4 ). Birth height increased from the lowest to the highest quartiles of Zn from animal sources ( $P$ for trend $=0.002$ ) and their proportion to total $\mathrm{Zn}$ intake $(P$ for trend $=0.002$ ), whereas it decreased with proportions of $\mathrm{Zn}$ from plant sources ( $P$ for trend $=0.006$ ). Birth weight and height increased from the lowest to the highest quartiles of the molar ratio of phytate: $\mathrm{Zn}$ ( $P$ for trend $=0.001$ and $0 \cdot 021$, respectively).

\section{Discussion}

We found that maternal $\mathrm{Zn}$ intake from animal food sources was positively associated with birth weight and height, but the percentage of $\mathrm{Zn}$ intake from plant food sources was negatively associated with birth height. The phytate: $\mathrm{Zn}$ ratio was negatively associated with birth weight in the present study.

Such beneficial effects of $\mathrm{Zn}$ from animal sources on fetal growth can be explained by the bioavailability of $\mathrm{Zn}$ differing with its food sources ${ }^{(12,24)}$. Zn present in animal foods such as meat, fish, eggs and milk is generally known to have a greater bioavailability than that found in plants because of the possible presence of phytate, a chelator of $\mathrm{Zn}$ that decreases its availability for absorption in the intestine ${ }^{(14,25)}$. Since diets that comprise mostly plant foods with a high phytate: $\mathrm{Zn}$ ratio result in low $\mathrm{Zn}$ absorption in humans ${ }^{(12,25,26)}$, the

Table 1. General characteristics of mothers and newborns

(Mean values, standard deviations, number of subjects and percentages)

\begin{tabular}{|c|c|c|c|c|c|}
\hline & \multirow[b]{2}{*}{ Subjects $(n)$} & \multirow[b]{2}{*}{ Mean } & \multirow[b]{2}{*}{$\mathrm{SD}$} & \multicolumn{2}{|c|}{ Subjects within category } \\
\hline & & & & $n$ & $\%$ \\
\hline \multicolumn{6}{|l|}{ Mothers } \\
\hline Age (years) & 915 & $30 \cdot 1$ & 3.7 & & \\
\hline Height (cm) & 895 & $161 \cdot 0$ & $4 \cdot 8$ & & \\
\hline Pre-pregnancy weight (kg) & 905 & $56 \cdot 1$ & 8.9 & & \\
\hline Pre-pregnancy BMI $\left(\mathrm{kg} / \mathrm{m}^{2}\right)$ & 893 & $21 \cdot 7$ & $3 \cdot 3$ & & \\
\hline Local centres & 918 & & & & \\
\hline Seoul & & & & 256 & $27 \cdot 9$ \\
\hline Ulsan & & & & 343 & $37 \cdot 4$ \\
\hline Cheonan & & & & 319 & $34 \cdot 7$ \\
\hline Education & 879 & & & & \\
\hline$\leq$ High school & & & & 255 & $29 \cdot 1$ \\
\hline$<$ University & & & & 151 & $17 \cdot 2$ \\
\hline$\geq$ University & & & & 473 & $53 \cdot 8$ \\
\hline Family income (US\$/month) & 876 & & & & \\
\hline$<2000$ & & & & 246 & $28 \cdot 8$ \\
\hline $2000-4000$ & & & & 451 & 52.9 \\
\hline$>4000$ & & & & 156 & $18 \cdot 3$ \\
\hline Current alcohol drinkers & 522 & & & 58 & $11 \cdot 1$ \\
\hline Ever smokers & 866 & & & 99 & $11 \cdot 4$ \\
\hline Current smokers & 915 & & & 0 & 0.0 \\
\hline Parity $(n)$ & 905 & 0.5 & 0.7 & & \\
\hline \multicolumn{6}{|l|}{ Newborns } \\
\hline Gestational age at birth (weeks) & 918 & $39 \cdot 3$ & $1 \cdot 1$ & & \\
\hline Birth weight (g) & 918 & 3297 & 385 & & \\
\hline Birth height $(\mathrm{cm})$ & 839 & $50 \cdot 7$ & $2 \cdot 3$ & & \\
\hline Neonatal sex & 915 & & & & \\
\hline Girls & & & & 450 & $49 \cdot 2$ \\
\hline Boys & & & & 465 & $50 \cdot 8$ \\
\hline
\end{tabular}


Table 2. Daily energy and zinc intake of pregnant women

(Mean values, standard deviations, medians and ranges, $n$ 918)

\begin{tabular}{|c|c|c|c|c|}
\hline & Mean & SD & Median & Range \\
\hline Energy $(\mathrm{kJ} / \mathrm{d})$ & $7419 \cdot 6$ & $2016 \cdot 5$ & 7212.9 & $2518 \cdot 7-16738 \cdot 3$ \\
\hline Carbohydrate (\% energy) & $61 \cdot 0$ & $9 \cdot 9$ & $60 \cdot 7$ & $24 \cdot 3-87 \cdot 2$ \\
\hline Protein (\% energy) & $15 \cdot 8$ & $4 \cdot 2$ & $15 \cdot 2$ & $6 \cdot 6-43 \cdot 5$ \\
\hline Fat (\% energy) & $24 \cdot 7$ & 8.5 & 23.4 & $3 \cdot 9-55 \cdot 6$ \\
\hline Total Zn intake $(\mathrm{mg} / \mathrm{d})^{*}$ & $9 \cdot 9$ & $5 \cdot 6$ & 8.4 & $2 \cdot 6-44 \cdot 7$ \\
\hline From foods $(\mathrm{mg} / \mathrm{d})$ & 8.4 & 3.5 & $7 \cdot 8$ & $2.5-40.5$ \\
\hline Animal $(\mathrm{mg} / \mathrm{d}) \dagger$ & $3 \cdot 4$ & $3 \cdot 0$ & 1.5 & $0.7-20 \cdot 0$ \\
\hline Plant $(\mathrm{mg} / \mathrm{d}) \ddagger$ & $4 \cdot 8$ & 1.8 & $1 \cdot 0$ & $0 \cdot 0-37 \cdot 2$ \\
\hline Others $(\mathrm{mg} / \mathrm{d}) \S$ & 0.2 & 0.3 & 0.2 & $0.0-7.3$ \\
\hline Animal (\% total Zn) & $37 \cdot 1$ & $17 \cdot 4$ & 35.5 & $0.0-90.9$ \\
\hline Plant (\% total Zn) & $60 \cdot 2$ & $17 \cdot 3$ & $61 \cdot 8$ & $9 \cdot 0-100$ \\
\hline Phytate intake (mg/d) & $626 \cdot 0$ & $331 \cdot 8$ & $570 \cdot 4$ & $20 \cdot 3-3017 \cdot 3$ \\
\hline Phytate:Zn molar ratio|| & $7 \cdot 7$ & $3 \cdot 8$ & $7 \cdot 2$ & $0.3-33 \cdot 7$ \\
\hline
\end{tabular}

* Includes food and supplements.

$\dagger$ Includes meat, fish, eggs and dairy products.

$\ddagger$ Includes grains, potatoes, legumes, fruit and vegetables, mushrooms, seaweeds, and nuts.

$\S$ Includes sweets, carbonated beverages, fats and oils, and condiments.

|| Phytate:Zn molar ratio = (phytate/phytate molecular weight $(660 \cdot 1)) /(\mathrm{Zn} / \mathrm{Zn}$ molecular weight $(65 \cdot 4))$.

issue of $\mathrm{Zn}$ bioavailability is important for populations with plant-dominated diets. The bioavailability of $\mathrm{Zn}$ is influenced by different foods, and $\mathrm{Zn}$ from animal foods is believed to be most bioavailable. Yokoi et al. ${ }^{(20)}$ reported that consumption of beef and other red meat measured by qualitative food frequency was positively associated with $\mathrm{Zn}$ pool size, and Velie et $a l^{(19)}$ found that increased total $\mathrm{Zn}$ intake and $\mathrm{Zn}$ intake from animal products were associated with a reduced risk for neural tube defects, suggesting that dietary Zn exerts differential effects on pregnancy outcome depending on the food source. It becomes even more important for pregnant women, because during pregnancy, the requirement for $\mathrm{Zn}$ is increased for the demands by fetal growth $^{(8,9,27)}$.

Another possible mechanism for the positive association between the high consumption of $\mathrm{Zn}$ from animal food sources and fetal growth is the high consumption of animal food itself, because of its protein content and an enhancing role of animal protein on $\mathrm{Zn}$ absorption. $\mathrm{Zn}$ absorption is reported to increase in a linear fashion with increasing protein consumption $^{(28)}$. Animal protein with a higher content of amino acids, such as histidine, cysteine and methionine, has been shown to counteract the inhibitory effects of phytate on $\mathrm{Zn}$ absorption ${ }^{(29)}$. However, we found no association between the intakes of either total or animal protein and fetal growth (data not shown).

In the present study, no association was observed between fetal growth and either total $\mathrm{Zn}$ intake from food only or that from food and supplements together, a finding that is consistent with the Glover \& Hogstrand study ${ }^{(30)}$, but contrasts with others who found a positive association ${ }^{(10,31)}$. Our finding of no association between total $\mathrm{Zn}$ intake from food and supplements on fetal growth might be due to only a small proportion (15\%) of our subjects taking dietary supplements containing $\mathrm{Zn}$, rendering the contribution of $\mathrm{Zn}$ from supplements negligible $(1.5 \mathrm{mg} / \mathrm{d})$. The results of prenatal $\mathrm{Zn}$ supplementation trials on fetal growth have been equivocal. Garg et al. ${ }^{(32)}$ found that Zn supplementation exhibited positive effects on birth weight and gestational age. However, Goldenberg et al. ${ }^{(9)}$ found a positive effect of $\mathrm{Zn}$ supplementation on fetal growth only for women with a BMI of $<26 \mathrm{~kg} / \mathrm{m}^{2}$.

The likelihood of mild-to-moderate $\mathrm{Zn}$ deficiency ${ }^{(33)}$ and lower plasma levels of $\mathrm{Zn}^{(34)}$ is higher in pregnant women

Table 3. Multiple regression analysis for the association between maternal zinc and phytate intakes, and birth weight and height* ${ }^{*} \beta$ Coefficients with their standard errors)

\begin{tabular}{|c|c|c|c|c|c|c|}
\hline & \multicolumn{3}{|c|}{ Birth weight ( $n$ 862) } & \multicolumn{3}{|c|}{ Birth height $(n 784)$} \\
\hline & $\beta$ & SE & $P$ & $\beta$ & SE & $P$ \\
\hline \multicolumn{7}{|l|}{ Zn intake } \\
\hline Total $(\mathrm{mg} / \mathrm{d})$ & 46277 & 27658 & 0.095 & 0.174 & 0.170 & 0.306 \\
\hline From foods $(\mathrm{mg} / \mathrm{d})$ & 57289 & 35332 & 0.105 & 0.165 & 0.217 & 0.447 \\
\hline Animal (mg/d) & 35043 & 16501 & 0.034 & 0.236 & $0 \cdot 101$ & 0.020 \\
\hline Plant $(\mathrm{mg} / \mathrm{d})$ & 13424 & 33391 & 0.688 & -0.070 & 0.207 & 0.735 \\
\hline Animal $(\%$ total $Z n)$ & 1.437 & 0.715 & 0.045 & 0.009 & 0.004 & 0.032 \\
\hline Plant (\% total Zn) & -1.205 & 0.717 & 0.093 & -0.010 & 0.004 & 0.026 \\
\hline Phytate intake (mg/d) & -22.755 & $22 \cdot 143$ & 0.304 & -0.140 & 0.139 & 0.313 \\
\hline Phytate:Zn molar ratio & -0.677 & 0.324 & 0.037 & -0.004 & 0.002 & 0.068 \\
\hline
\end{tabular}

* Multiple regression analysis adjusted for maternal age, pre-pregnancy BMI, neonatal sex, gestational age at delivery, parity, level of education, local centres and level of education $\times$ local centres. 
Table 4. Birth weight and height according to the quartiles of zinc and phytate intakes of pregnant women*

(Mean values and standard deviations)

\begin{tabular}{|c|c|c|c|c|}
\hline & \multicolumn{2}{|c|}{$\begin{array}{l}\text { Birth weight }(\mathrm{g}) \\
\quad(n \text { 862) }\end{array}$} & \multicolumn{2}{|c|}{$\begin{array}{l}\text { Birth height } \\
(\mathrm{cm})(n 784)\end{array}$} \\
\hline & Mean & SD & Mean & SD \\
\hline \multicolumn{5}{|l|}{ Total $\mathrm{Zn}$ intake $(\mathrm{mg} / \mathrm{d})$} \\
\hline Lowest $(\leq 6.53)$ & 3280 & 377 & $50 \cdot 0$ & $2 \cdot 3$ \\
\hline Second (6.54-8.35) & 3255 & 392 & $50 \cdot 0$ & 2.5 \\
\hline Third (8.36-11.45) & 3320 & 378 & $50 \cdot 0$ & $2 \cdot 2$ \\
\hline Highest $(>11.49)$ & 3300 & 392 & $51 \cdot 0$ & $2 \cdot 0$ \\
\hline$P$ for trend & \multicolumn{2}{|c|}{0.234} & \multicolumn{2}{|c|}{0.276} \\
\hline \multicolumn{5}{|l|}{ Zn intake from foods $(\mathrm{mg} / \mathrm{d})$} \\
\hline Lowest $(\leq 6 \cdot 27)$ & 3280 & 377 & $50 \cdot 0$ & $2 \cdot 3$ \\
\hline Second $(6 \cdot 28-7 \cdot 85)$ & 3215 & 385 & $50 \cdot 0$ & 2.4 \\
\hline Third $(7.86-9.79)$ & 3320 & 388 & 50.5 & $2 \cdot 3$ \\
\hline Highest (>9.79) & 3320 & 389 & $51 \cdot 0$ & $2 \cdot 1$ \\
\hline$P$ for trend & \multicolumn{2}{|c|}{0.039} & \multicolumn{2}{|c|}{0.202} \\
\hline \multicolumn{5}{|c|}{$\mathrm{Zn}$ intake from animal foods $(\mathrm{mg} / \mathrm{d})$} \\
\hline Lowest $(\leq 1.67)$ & 3250 & 383 & $50 \cdot 0$ & $2 \cdot 2$ \\
\hline Second $(1.68-2.69)$ & 3230 & 376 & $50 \cdot 0$ & 2.5 \\
\hline Third $(2 \cdot 70-4 \cdot 17)$ & 3265 & 368 & $50 \cdot 9$ & $2 \cdot 3$ \\
\hline Highest $(>4.18)$ & 3400 & 406 & $51 \cdot 0$ & $2 \cdot 1$ \\
\hline$P$ for trend & \multicolumn{2}{|c|}{0.002} & \multicolumn{2}{|c|}{0.002} \\
\hline \multicolumn{5}{|c|}{$\mathrm{Zn}$ intake from plant foods $(\mathrm{mg} / \mathrm{d})$} \\
\hline Lowest ( $\leq 3.72)$ & 3290 & 375 & 50.5 & $2 \cdot 4$ \\
\hline Second $(3.73-4.68)$ & 3340 & 395 & $51 \cdot 0$ & $2 \cdot 3$ \\
\hline Third $(4.69-5.67)$ & 3200 & 403 & $50 \cdot 5$ & $2 \cdot 2$ \\
\hline Highest $(>5.67)$ & 3290 & 367 & $50 \cdot 0$ & $2 \cdot 1$ \\
\hline$P$ for trend & \multicolumn{2}{|c|}{0.861} & \multicolumn{2}{|c|}{0.307} \\
\hline \multicolumn{5}{|c|}{$\mathrm{Zn}$ intake from aniaml foods (\% total $\mathrm{Zn}$ ) } \\
\hline Lowest $(\leq 24.6)$ & 3260 & 384 & $50 \cdot 0$ & $2 \cdot 2$ \\
\hline Second $(24.6-35.5)$ & 3220 & 358 & $50 \cdot 0$ & $2 \cdot 2$ \\
\hline Third (35.6-49.4) & 3300 & 403 & $51 \cdot 0$ & $2 \cdot 4$ \\
\hline Highest $(>49.5)$ & 3340 & 393 & $51 \cdot 0$ & $2 \cdot 2$ \\
\hline$P$ for trend & \multicolumn{2}{|c|}{0.026} & \multicolumn{2}{|c|}{0.002} \\
\hline \multicolumn{5}{|c|}{$\mathrm{Zn}$ intake from plant foods (\% total Zn) } \\
\hline Lowest $(\leq 47 \cdot 8)$ & 3320 & 387 & $51 \cdot 0$ & $2 \cdot 2$ \\
\hline Second $(47 \cdot 9-61 \cdot 8)$ & 3300 & 405 & $51 \cdot 0$ & $2 \cdot 3$ \\
\hline Third $(61.9-72.6)$ & 3224 & 365 & $50 \cdot 5$ & $2 \cdot 3$ \\
\hline Highest $(>72.7)$ & 3250 & 383 & $50 \cdot 0$ & $2 \cdot 3$ \\
\hline$P$ for trend & \multicolumn{2}{|c|}{0.115} & \multicolumn{2}{|c|}{0.006} \\
\hline \multicolumn{5}{|l|}{ Phytate intake (mg/d) } \\
\hline Lowest $(\leq 404 \cdot 6)$ & 3298 & 379 & $51 \cdot 0$ & $2 \cdot 3$ \\
\hline Second $(404 \cdot 7-570 \cdot 4)$ & 3324 & 393 & $51 \cdot 0$ & $2 \cdot 3$ \\
\hline Third (570.5-787.9) & 3283 & 390 & $51 \cdot 0$ & $2 \cdot 3$ \\
\hline Highest $(>788.0)$ & 3281 & 378 & $50 \cdot 4$ & $2 \cdot 3$ \\
\hline$P$ for trend & \multicolumn{2}{|c|}{0.613} & & \\
\hline Phytate:Zn molar ratio & & & & \\
\hline Lowest $(\leq 5.06)$ & 3340 & 419 & $51 \cdot 0$ & $2 \cdot 2$ \\
\hline Second (5.07-7.19) & 3305 & 367 & $51 \cdot 0$ & $2 \cdot 3$ \\
\hline Third $(7 \cdot 20-9 \cdot 80)$ & 3281 & 352 & $50 \cdot 5$ & $2 \cdot 1$ \\
\hline Highest $(>9.81)$ & 3260 & 386 & $50 \cdot 4$ & $2 \cdot 3$ \\
\hline$P$ for trend & & & & \\
\hline
\end{tabular}

* General linear models adjusted for maternal age, pre-pregnancy BMI, neonata sex, gestational age at delivery, parity, level of education, local centres and level of education $\times$ local centres.

than in non-pregnant women. Despite a recent increasing trend of animal food consumption and a subsequent improvement in overall $\mathrm{Zn}$ bioavailability ${ }^{(35)}$, approximately $54 \%$ of the Korean population has an inadequate $\mathrm{Zn}$ intake due to the traditionally high intake of white rice and vegetables ${ }^{(14)}$. The situation could be more critical for pregnant women, because the nutritional requirement for $\mathrm{Zn}$ is increased during pregnancy to meet the demands of fetal growth and the maintenance of maternal health. The mean dietary $\mathrm{Zn}$ intake from foods was $8.4 \mathrm{mg} / \mathrm{d}$ in our subjects, which is comparable with that among pregnant women in both China $^{(36)}$ and England ${ }^{(37)}$, but lower than that reported in the $\mathrm{USA}^{(38)}$ and New Zealand ${ }^{(39)}$. The estimated mean Zn intakes from animal and plant food sources of our subjects were 3.4 and $4.8 \mathrm{mg} / \mathrm{d}$, respectively, indicating that about $40 \%$ of the dietary $\mathrm{Zn}$ was derived from animal foods. Although several studies have found that both the total amount of $\mathrm{Zn}$ intake and its bioavailability are important for fetal growth during pregnancy ${ }^{(13-15)}$, our findings suggest that fetal growth is influenced more by the bioavailability of $\mathrm{Zn}$ than by the absolute amount of $\mathrm{Zn}$ intake.

The present study has a few limitations. We did not measure plasma $\mathrm{Zn}$ concentrations that are considered to be a more objective means to assess $\mathrm{Zn}$ status than dietary $\mathrm{Zn}$ intake data alone, and a $1 \mathrm{~d}, 24 \mathrm{~h}$ recall may not be sufficient to assess usual daily intake due to large intra-individual variability in food and nutrient intake, but trained dietitians using standard protocols were employed to help the subjects reflect on their daily diet to minimise variation if it existed. There are other possible mechanisms of a positive effect of a higher consumption of animal foods for better fetal growth. These include the increased intakes of other amino acids (methionine, etc.), of which adequate intakes are known to be important for fetal growth ${ }^{(40)}$; however, we were not able to distinguish such a possibility. Further studies are warranted to clarify these issues. Nonetheless, to our knowledge, this is the first study involving a large prospective cohort to investigate the relationship between maternal intake of $\mathrm{Zn}$ from different food sources and fetal growth among pregnant women in Korea, where the food source is predominantly of plant origin with high phytate content.

In conclusion, we found that the maternal dietary $\mathrm{Zn}$ intake from animal foods may have a positive effect on fetal growth. Therefore, an adequate $\mathrm{Zn}$ intake from animal foods that are particularly rich sources of $\mathrm{Zn}$ should be recommended for pregnant women to promote optimal fetal growth. The findings of the present study could help in the further development of public health policies to improve nutritional status of $\mathrm{Zn}$ during pregnancy.

\section{Acknowledgements}

The present study was supported by the Mothers and Children's Environmental Health project of the Ministry of Environment, Republic of Korea. None of the authors has any conflicts of interest to declare. Y. A. L. conducted the statistical analyses and wrote the manuscript. J.-Y. H. assisted in the study design and analyses, and wrote the manuscript. Y. A. L. and H. K. collected the dietary data. E.-H. H., H. P., M. H., Y. K. and Y.-C. H. conducted the research. N. C. designed the study and supervised all aspects of its implementation. All authors contributed to the preparation of the manuscript and approved the final version submitted for publication. 


\section{References}

1. McCall KA, Huang C \& Fierke CA (2000) Function and mechanism of zinc metalloenzymes. J Nutr 130, 1437S-1446S.

2. Hadley KB, Newman SM \& Hunt JR (2010) Dietary zinc reduces osteoclast resorption activities and increases markers of osteoblast differentiation, matrix maturation, and mineralization in the long bones of growing rats. J Nutr Biochem 21, 297-303.

3. Cousins RJ (1998) A role of zinc in the regulation of gene expression. Proc Nutr Soc 57, 307-311.

4. Swanson CA \& King JC (1987) Zinc and pregnancy outcome. Am J Clin Nutr 46, 763-771.

5. Mutch PB \& Hurley LS (1974) Effect of zinc deficiency during lactation on postnatal growth and development of rats. $J$ Nutr 104, 828-842.

6. Kynast G \& Saling E (1980) The relevance of zinc in pregnancy. J Perinat Med 8, 171-182.

7. Apgar J (1985) Zinc and reproduction. Ann Rev Nutr 5, 43-68.

8. Tamura T \& Goldenberg RL (1996) Zinc nutriture and pregnancy outcome. Nutr Res 16, 139-181.

9. Goldenberg RL, Tamura T, Neggers Y, et al. (1995) The effect of zinc supplementation on pregnancy outcome. JAMA 274, $463-468$

10. Merialdi M, Caulfield LE, Zavaleta N, et al. (2004) Randomized controlled trial of prenatal zinc supplementation and fetal bone growth. Am J Clin Nutr 79, 826-830.

11. Danesh A, Janghorbani M \& Mohammadi B (2010) Effects of zinc supplementation during pregnancy on pregnancy outcome in women with history of preterm delivery: a double-blind randomized, placebo-controlled trial. J Matern Fetal Neonatal Med 23, 403-408.

12. Oberleas D \& Harland BF (1981) Phytate content of foods: effect of dietary zinc bioavailability. J Am diet Ass 79, 433-436

13. Hunt JR, Beiseigel JM \& Johnson LK (2008) Adaptation in human zinc absorption as influenced by dietary zinc and bioavailability. Am J Clin Nutr 87, 1336-1345.

14. Joung H, Nam G, Yoon S, et al. (2004) Bioavailable zinc intake of Korean adults in relation to the phytate content of Korean foods. J Food Compost Anal 17, 713-724.

15. Ma G, Li Y, Jin Y, et al. (2007) Assessment of intake inadequacy and food sources of zinc of people in China. Public Health Nutr 10, 848-854.

16. Alloway BJ (2004) Zinc in soils and crop nutrition. Brussels: International Zinc Association Publication, pp. 1-116.

17. Korea Institute of Health and Social Affairs (2009) The Fourth Korea National Health and Nutrition Examination Survey (KNHANES) - Nutrition Survey, Seoul, Korea.

18. Gibson RS, Yeudall F, Drost N, et al. (1998) Dietary interventions to prevent zinc deficiency. Am J Clin Nutr 68, $484 \mathrm{~S}-487 \mathrm{~S}$.

19. Velie EM, Block G, Shaw GM, et al. (1999) Maternal supplemental and dietary zinc intake and the occurrence of neural tube defects in California. Am J Epidemiol 150, 605-616

20. Yokoi K, Sandstead HH, Egger NG, et al. (2007) Association between zinc pool sizes and iron stores in premenopausal women without anaemia. Br J Nutr 98, 1214-1223.
21. Kim BM, Ha M, Park HS, et al. (2009) The Mothers and Children's Environmental Health (MOCEH) study. Eur J Epidemiol 24, 573-583.

22. Kim H, Lee HJ, Hwang JY, et al. (2010) Blood cadmium concentrations of male cigarette smokers are inversely associated with fruit consumption. J Nutr 140, 1133-1138.

23. Harland BF \& Oberleas D (1987) Phytate in foods. World Rev Nutr Diet 52, 235-259.

24. Etcheverry P, Hawthorne KM, Liang LK, et al. (2006) Effect of beef and soy proteins on the absorption of non-heme iron and inorganic zinc in children. $J$ Am Coll Nutr 25, 34-40.

25. Kim J, Paik HY, Joung H, et al. (2007) Effect of dietary phytate on zinc homeostasis in young and elderly Korean women. J Am Coll Nutr 26, 1-9.

26. Liang J, Han BZ, Nout MJ, et al. (2010) In vitro solubility of calcium, iron and zinc in relation to phytic acid levels in rice-based consumer products in China. Int J Food Sci Nutr 61, $40-51$.

27. Shah D \& Sachdev HP (2006) Zinc deficiency in pregnancy and fetal outcome. Nutr Rev 64, 15-30.

28. Sandström B, Almgren A, Kivistö B, et al. (1989) Effect of protein level and protein source on zinc absorption in humans. J Nutr 119, 48-53.

29. Lönnerdal B (2000) Dietary factors influencing zinc absorption. J Nutr 130, 1378S-1383S

30. Glover CN \& Hogstrand C (2002) Amino acid modulation of in vivo intestinal zinc absorption in freshwater rainbow trout. $J$ Exp Biol 205, 151-158.

31. Yang YX, Chen XC, Lin JY, et al. (2000) Effect of zinc intake on fetal and infant growth among Chinese pregnant and lactating women. Biomed Environ Sci 13, 280-286.

32. Garg HK, Singhal KC \& Arshad Z (1993) A study of the effect of oral zinc supplementation during pregnancy on pregnancy outcome. Indian J Physiol Pharmacol 37, 276-284.

33. Caulfield LE, Zvaleta N, Shankar A, et al. (1998) Potential contribution of maternal zinc supplementation during pregnancy to maternal and child survival. Am J Clin Nutr $\mathbf{6 8}$, 4995-5085.

34. Swanson CA \& King JC (1983) Reduced serum zinc concentration during pregnancy. Obstet Gynecol 62, 313-318.

35. Kwun IS, Do MS, Chung HR, et al. (2009) The impact of rapid economic growth and globalization on zinc nutrition in South Korea. Public Health Nutr 12, 1234-1241.

36. Cheng Y, Dibley MJ, Zhang X, et al. (2009) Assessment of dietary intake among pregnant women in a rural area of western China. BMC Public Health 9, 222-230.

37. Mouratidou T, Ford F, Prountzou F, et al. (2006) Dietary assessment of a population of pregnant women in Sheffield, UK. Br J Nutr 96, 929-935.

38. Litonjua AA, Rifas-Shiman SL, Ly NP, et al. (2006) Maternal antioxidant intake in pregnancy and wheezing illnesses in children at $2 \mathrm{y}$ of age. Am J Clin Nutr 84, 903-911.

39. Watson PE \& McDonald BW (2009) Major influences on nutrient intake in pregnant New Zealand women. Matern Child Health J 13, 695-706.

40. Dasarathy J, Gruca LL, Bennett C, et al. (2010) Methionine metabolism in human pregnancy. Am J Clin Nutr 91, $357-365$. 